\title{
Routes of non-traditional entry into buprenorphine treatment programs
}

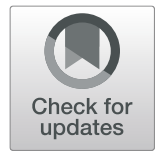

\author{
Tiffany Champagne-Langabeer ${ }^{1}$, Michael W. Swank ${ }^{1}$ and James R. Langabeer $\|{ }^{1,2^{*}}$ (D)
}

\begin{abstract}
Background: Excessive prescribing, increased potency of opioids, and increased availability of illicit heroin and synthetic analogs such as fentanyl has resulted in an increase of overdose fatalities. Medications for opioid use disorder (MOUD) significantly reduces the risk of overdose when compared with no treatment. Although the use of buprenorphine as an agonist treatment for opioid use disorder (OUD) is growing significantly, barriers remain which can prevent or delay treatment. In this study we examine non-traditional routes which could facilitate entry into buprenorphine treatment programs.

Methods: Relevant, original research publications addressing entry into buprenorphine treatment published during the years 1989-2019 were identified through PubMed, PsychInfo, PsychArticles, and Medline databases. We operationalized key terms based on three non-traditional paths: persons that entered treatment via the criminal justice system, following emergencies, and through community outreach.

Results: Of 462 screened articles, twenty studies met the inclusion criteria for full review. Most studies were from the last several years, and most (65\%) were from the Northeastern region of the United States. Twelve (60\%) were studies suggesting that the criminal justice system could be a potentially viable entry route, both pre-release or post-incarceration. The emergency department was also found to be a cost-effective and viable route for screening and identifying individuals with OUD and linking them to buprenorphine treatment. Fewer studies have documented community outreach initiatives involving buprenorphine. Most studies were small sample size (mean $=<200$ ) and $40 \%$ were randomized trials.
\end{abstract}

Conclusions: Despite research suggesting that increasing the number of Drug Addiction Treatment Act (DATA) waived physicians who prescribe buprenorphine would help with the opioid treatment gap, little research has been conducted on routes to increase utilization of treatment. In this study, we found evidence that engaging individuals through criminal justice, emergency departments, and community outreach can serve as non-traditional treatment entry points for certain populations. Alternative routes could engage a greater number of people to initiate MOUD treatment.

Keywords: Opioid use disorder, Buprenorphine, Treatment, Addiction

\section{Background}

The continuous growth in the United States opioid epidemic has resulted in a significant number of lives lost and families destroyed, creating a public health emergency. From the years 1999 to 2016, over 351,000 people died of opioid-related causes [1], and according to a recent US Surgeon General Report, the overall cost of the

\footnotetext{
* Correspondence: James.R.Langabeer@uth.tmc.edu

${ }^{1}$ School of Biomedical Informatics, University of Texas Health Science Center, Houston, TX, USA

${ }^{2}$ McGovern Medical School, University of Texas Health Science Center, 7000 Fannin Street, Suite 600, Houston, TX 77030, USA
}

opioid crisis in 2015 was over $\$ 500$ billion [2]. The current national estimate is that 2 million individuals live with opioid use disorder (OUD), and a significant majority of these historically have not received agonist treatment (or medication-assisted treatment), leaving a large treatment gap despite improvements during the last few years $[3,4]$.

There are three FDA-approved medications to treat OUD: the partial opioid agonist buprenorphine, agonist methadone, and extended release naltrexone, an opioid antagonist. A recent study found that opioid agonist

(c) The Author(s). 2020 Open Access This article is distributed under the terms of the Creative Commons Attribution 4.0 International License (http://creativecommons.org/licenses/by/4.0/), which permits unrestricted use, distribution, and 
treatment cuts the risk of overdose fatality risk in half compared to no treatment [5]. Other studies and reports concur that MOUD saves lives and prevents relapses and other negative consequences [6;7]. The challenge now remains how to get those affected into medical and behavioural treatment programs $[3,6]$. Traditional paths of entry require patients to initiate or self-present for treatment to a provider or clinic.

In a study analysing data from 2013 to 2018 in the US, 350,000 patients with OUD were being treated with methadone and 112,000 with buprenorphine [7], although the most recent national drug use survey suggests that buprenorphine has made significant gains in 2017 and 2018 [8]. Although expansion of methadone treatment facilities has occurred, full penetration may be limited due to geographical constraints; furthermore, many counties, especially rural ones, have no methadone treatment programs at all [9].

Buprenorphine, unlike methadone, does not need to be administered in a drug treatment facility; and studies have shown that both in-office and home induction are effective $[10,11]$. Buprenorphine can also be combined with an antagonist naloxone to limit the recreational potential and street value, as well as potential diversion relative to methadone [11]. A recent study from the United Kingdom also found that buprenorphine was significantly safer than methadone and had a lower toxicity profile with less risk of accidental overdose and death [12].

The small number of patients receiving buprenorphine/ naloxone (hereafter called buprenorphine) suggests that treatment opportunities could be greatly expanded [13]. Increasing capacity of qualified and willing prescribers is necessary, but increased access does not necessarily translate to increased use. To ensure patients utilize treatment, they must first find entry into a program or provider; and the traditional model may not be feasible for a number of reasons. For this research, we define a traditional model of care where a patient requests and initiates treatment at an outpatient or inpatient clinic for an illness or disease, symptom, or disease. In reality, there are a multitude of barriers which impeded this model when seeking care for OUD include knowledge (e.g. what is MOUD?), geography (e.g. where can I find help?), financial (e.g. can I afford treatment?), and stigma (i.e. discrimination based on perception). In this review, we chose instead to focus on how persons with OUD are brought into treatment through non-traditional routes. We were primarily interested in entry into buprenorphine treatment through an emergency route (e.g. an encounter with hospital emergency departments), the criminal justice system, or facilitated by community or public health outreach.

Persons with OUD who experience an overdose on injected opioids may end up in the emergency room [1417]. This creates an opportunity for change and makes this one potential route of buprenorphine induction. Illicit opioid use places individuals at an increased risk of interaction with the criminal justice system, including incarceration [18]. However, studies show the availability of MOUD, including buprenorphine, is very low in criminal justice settings [19], and this represents a missed opportunity for treatment. Finally, public health outreach is one other possible means of engaging patients into treatment. Previous studies have shown outreach to be useful in engaging patients in methadone treatment [20]; however, very little has been published on its application to buprenorphine treatment induction [21]. While methadone has multiple barriers to increased utilization (e.g., geographic barriers and stringent dispensing guidelines), buprenorphine can be prescribed by any physician that has met the training and license requirements set forth by the Drug Enforcement Agency (DEA) Drug Addiction Treatment Act of 2000 (DATA 2000) and nurse practitioners and physician assistants who have met the training and licensure requirements set forth by the Comprehensive Addiction and Recovery Act of 2016 (CARA) [22].

Our research focuses on how patients with OUD initially obtained treatment with buprenorphine. In selecting this research, we were driven in part by a perceived deficit in studies that looked at strategies to link patients to buprenorphine treatment through less conventional routes. The aim of this study is to examine the literature on buprenorphine treatment entry resulting from nontraditional routes, including emergency, criminal justice, and outreach settings.

\section{Methods}

We conducted a systematic search and narrative review of the literature over the last 30 years (1989-2019) to evaluate the landscape of existing research for non-traditional routes to buprenorphine. The search was performed between March-April 2019 by the first and second authors. Four databases were included in this review: PubMed, PsychInfo, PsychArticles, and Medline. Search terms included a combination of medical subject headings $(\mathrm{MeSH})$ and key words for PubMed, and key words for the remaining databases. A complete list of terms is found in Table 1.

Criteria for initial inclusion were the following: original research report in a peer-reviewed journal that explicitly examined buprenorphine treatment initiated either through an emergency department or emergency hospitalization, within or associated with the criminal justice system, or through community outreach. Measured outcomes had to include effects of buprenorphine treatment on retention, opioid use, opioid positive urine toxicology, re-incarceration, or other health outcomes such as hospitalization, utilization of emergency facilities, or death. International studies were included if the report was in English and available for review. Papers were excluded if they: did not present original 
Table 1 Search strategy and search terms

\begin{tabular}{|c|c|c|c|c|}
\hline \multicolumn{5}{|l|}{ Search Strategy } \\
\hline \multicolumn{5}{|l|}{ PubMed Database } \\
\hline $\begin{array}{l}\text { opiate substitution treatment [Mesh] } \\
\text { OR opioid-related disorders/drug } \\
\text { therapy [Mesh] OR opioid-related } \\
\text { disorders/ rehabilitation [Mesh] }\end{array}$ & AND & $\begin{array}{l}\text { buprenorphine/ therapeutic use } \\
\text { [MeSH] OR buprenorphine [MeSH] }\end{array}$ & AND & $\begin{array}{l}\text { law enforcement }[\mathrm{MeSH}] \text { OR } \\
\text { criminal law }[\mathrm{MeSH}] \mathrm{OR} \text { incarceration } \\
\text { OR prisons [MeSH] OR prisons OR prison OR } \\
\text { emergency responders [MeSH] OR emergency } \\
\text { treatment [MeSH] OR emergency medical } \\
\text { services [MeSH] OR emergency service, } \\
\text { hospital [MeSH] } \\
\text { OR } \\
\text { outreach OR induction }\end{array}$ \\
\hline \multicolumn{5}{|c|}{ Psychlnfo, PsychArticles, and Medline Databases } \\
\hline $\begin{array}{l}\text { opiate substitution treatment OR } \\
\text { opioid-related disorders OR } \\
\text { drug therapy OR opioid-related } \\
\text { disorders OR rehabilitation }\end{array}$ & AND & $\begin{array}{l}\text { buprenorphine OR buprenorphine } \\
\text { therapy OR buprenorphine treatment }\end{array}$ & AND & $\begin{array}{l}\text { law enforcement OR criminal law OR } \\
\text { criminal justice OR incarceration OR prisons } \\
\text { OR prison OR } \\
\text { emergency responders OR emergency } \\
\text { treatment OR emergency medical services } \\
\text { OR emergency department OR emergency room } \\
\text { OR } \\
\text { outreach OR community programs OR induction }\end{array}$ \\
\hline
\end{tabular}

research; were reviews, commentaries, or editorials; were individual case reviews; were published in a language other than English; were published prior to 1989; did not report any outcome data; or did not address entry into buprenorphine treatment.

The initial search of 499 articles were indexed in an open access, web tool for review and abstraction [23]. After removing duplicates, a total of 462 citations remained. The first two authors performed a narrative review based on information obtained from titles and abstracts and applied inclusion and exclusion criteria, excluding 429 articles. Full-text articles were then examined further for inclusion/exclusion. An additional 13 articles were excluded because they did not report any outcome data $(n=9)$, or they were not relevant $(n=4)$, i.e., they did not address entry into buprenorphine treatment through an emergency route, criminal justice system, or facilitated by outreach. Twenty articles were selected for final inclusion and assessment. A schematic of the full search process is shown in Fig. 1.

\section{Results}

We identified 20 articles with non-traditional routes of entry into buprenorphine. We found that the northeast region of the U.S. had the highest number of studies. Only one study from was from the South (Alabama), leaving the West and Midwest unrepresented in this cross-section of studies. Eight (40\%) were RCT study designs, 35\% retrospective analysis studies, and the remainder were pilot or cohort studies. The majority of the research was heavily concentrated towards the most recent years. All but 2 (90\%) were small sample size studies, averaging less than 200 patients. Three articles focused on emergency settings; five were related to community outreach; and the majority (12) were related to criminal justice. Table 2 presents a summary of the studies included in this review.

\section{Entry into treatment from the emergency department}

D'Onofrio et al. (2015) examined emergency department (ED)-initiated buprenorphine treatment in a randomized controlled trial (RCT) with 329 opioid dependent patients [24]. After screening, patients were randomized to intervention groups. The primary outcome measure was engagement and retention in treatment at 30 days; secondary outcomes included number of days of illicit drug use and use of addiction treatment services. The main findings from this study concluded that ED-initiated buprenorphine treatment significantly increased engagement in addiction treatment and decreased use of inpatient addiction treatment services. The authors concluded that although this study supports the use of ED-initiated buprenorphine, replication in other settings would be required before widespread implementation. A secondary analysis of this study looked at long-term outcomes at 2, 6, and 12 months following ED-initiated buprenorphine [25]. Patients were transitioned to outpatient treatment settings where they received buprenorphine (or tapered off the medication) and were followed over a 12-month period. Measured outcomes included treatment engagement, illicit drug use, HIV risk, and urine toxicology. Although the buprenorphine group had greater engagement and lower self-reported illicit drug use at 2 months, these differences did not persist at the 6- and 12-month time points [25].

Busch and colleagues (2017) examined the costeffectiveness of ED-initiated buprenorphine in a subset of patients $(n=244)$ after completion of a 30-day assessment [26]. Cost measures included utilization of healthcare and treatment resources, labor costs of medical 


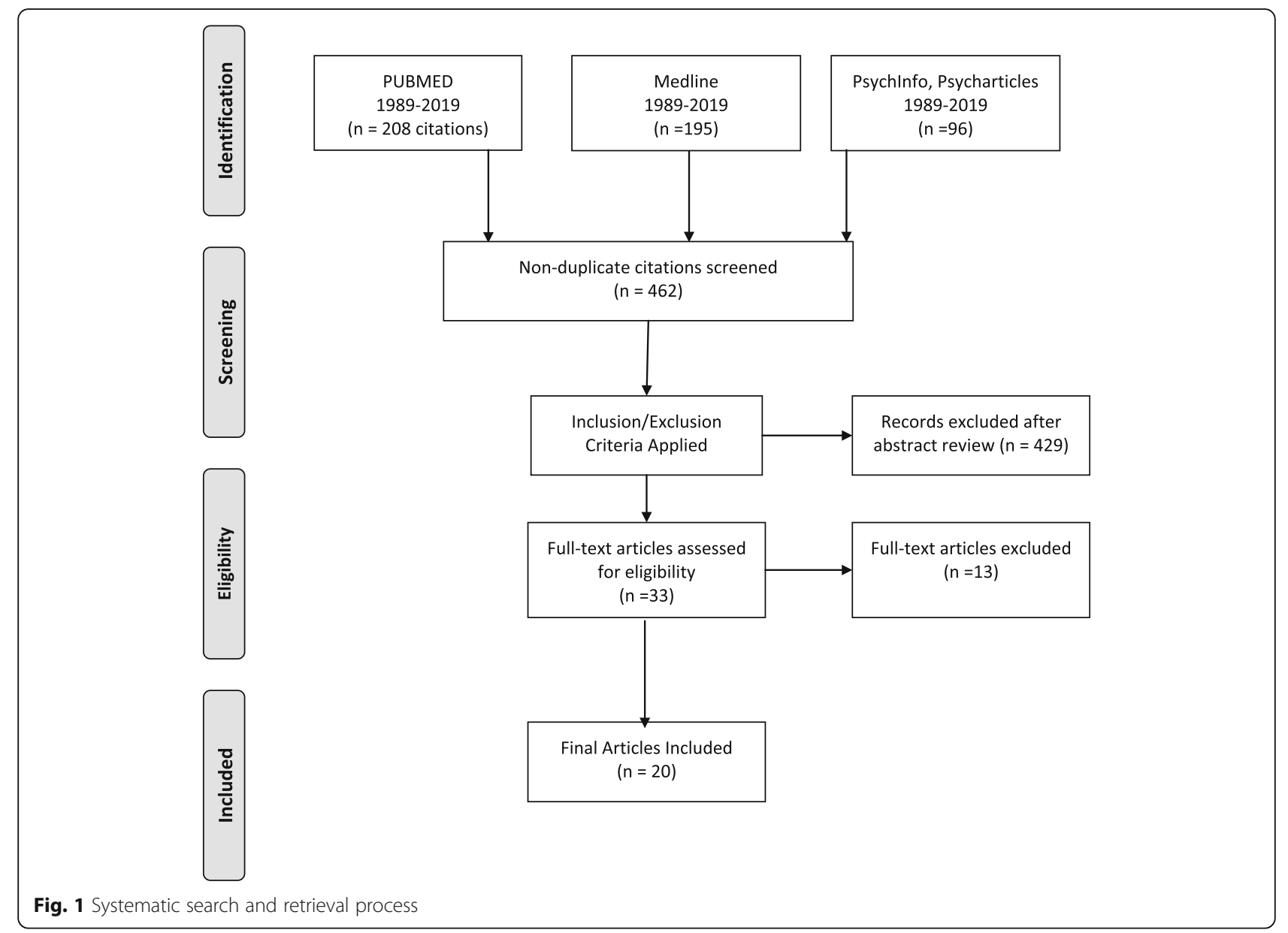

practitioners involved in treatment, drug costs, costs associated with crime, and patient time costs. They also concluded that overall ED-initiated buprenorphine was a cost-effective treatment option. The conclusion here was that ED-initiated buprenorphine is a cost-effective and useful route to engagement in MOUD, but additional work remains to determine how to best retain patients in long-term treatment with the goal of reducing or eliminating illicit opioid use.

\section{Seeking patients through outreach}

In a randomized controlled trial from Liebschutz et al. (2014), opioid-dependent patients hospitalized for reasons other than opioid dependence were recruited from an inpatient facility [27]. The study compared a 5-day buprenorphine taper with buprenorphine induction and transition to maintenance therapy. Measured outcomes were entry into maintenance treatment, retention at 1,3 , and 6 months, and self-reported prior 30-day use of illicit opioids. Buprenorphine linkage was associated with more favourable outcomes than detoxing alone in terms of entry (72.2 vs $11.9 \%)$, 6-month retention (16.7 vs $3.0 \%$, and illicit opioid use. A secondary analysis looking at illicit opioid use at 1, 3, and 6 months found no differences [28]. An additional brief report looked at predictors of treatment engagement and found previous buprenorphine treatment, more days hospitalized, and higher symptoms of post-traumatic stress disorder (PTSD) predicted higher number of days in office-based buprenorphine therapy [29]. A study which recruited patients through community fliers found patients inducted into buprenorphine treatment during the first week of treatment with bi-weekly visits up to 12 weeks showed better outcomes than wait-listing on all measures, and retention at 12 weeks was $70 \%$ [30]. Patients rated the program highly and money spent on drugs decreased.

The final outreach study looked at how buprenorphine treatment affects ED use and hospitalizations [31]. Patients were recruited from the New Haven, CT Community Healthcare Van (CHCV), which is linked to the syringe exchange program and is the first mobile induction and maintenance program in the US. They found that buprenorphine treatment reduced ED utilization but had no effect on number of hospitalizations or length of stay. 
Table 2 Summary of included study characteristics and findings

\begin{tabular}{|c|c|c|c|c|c|c|c|c|}
\hline \# & Article & $\begin{array}{l}\text { Study } \\
\text { Design }\end{array}$ & Sample & $\begin{array}{l}\text { Route } \\
\text { of } \\
\text { Entry }\end{array}$ & Intervention & Results & Conclusion & Limitations \\
\hline 1 & $\begin{array}{l}\text { Gordon } \\
\text { et al., } 2018\end{array}$ & RA & $\begin{array}{l}N= \\
199\end{array}$ & CJ & $\begin{array}{l}\text { Initiating buprenorphine } \\
\text { treatment prior to versus } \\
\text { after release from prison. }\end{array}$ & No significant differences. & $\begin{array}{l}\text { Treatment condition did } \\
\text { not predict likelihood of } \\
\text { arrest. }\end{array}$ & $\begin{array}{l}\text { Number of rearrests may } \\
\text { have been biased. During } \\
\text { the following } 12 \text { months } \\
\text { after release, many remain } \\
\text { detained. }\end{array}$ \\
\hline 2 & $\begin{array}{l}\text { Busch } \\
\text { et al., } 2017\end{array}$ & RCT & $\begin{array}{l}N= \\
329\end{array}$ & ED & $\begin{array}{l}\text { Cost-effectiveness of ED- } \\
\text { initiated buprenorphine. }\end{array}$ & $\begin{array}{l}\text { Patient costs significantly } \\
\text { lower in ED-initiated treat- } \\
\text { ment group. }\end{array}$ & $\begin{array}{l}\text { ED-initiated buprenorphine } \\
\text { treatment is cost-effective. }\end{array}$ & $\begin{array}{l}\text { Comparability of data. } \\
\text { Length of follow-up was } \\
\text { 30-days post- } \\
\text { randomization. }\end{array}$ \\
\hline 3 & $\begin{array}{l}\text { Lee et al., } \\
2017\end{array}$ & RCT & $N=72$ & O & $\begin{array}{l}\text { Predictors of retention in } \\
\text { office-based treatment } \\
\text { after hospitalization. }\end{array}$ & $\begin{array}{l}\text { Prior treatment, older age, } \\
\text { and non-minority status } \\
\text { were associated with more } \\
\text { time in office-based opioid } \\
\text { treatment. }\end{array}$ & $\begin{array}{l}\text { Linking hospitalized } \\
\text { patients to office treatment } \\
\text { may improve addiction } \\
\text { treatment. }\end{array}$ & $\begin{array}{l}\text { Small sample size; no } \\
\text { measures of mental } \\
\text { disorders other than PTSD. }\end{array}$ \\
\hline 4 & $\begin{array}{l}\text { Gordon } \\
\text { et al., } 2017\end{array}$ & RCT & $\begin{array}{l}N= \\
211\end{array}$ & CJ & $\begin{array}{l}\text { Initiating buprenorphine } \\
\text { treatment prior to versus } \\
\text { after release from prison. }\end{array}$ & $\begin{array}{l}\text { In-prison group had higher } \\
\text { number of treatment days } \\
\text { after release than those } \\
\text { who without treatment in } \\
\text { prison. }\end{array}$ & $\begin{array}{l}\text { In-prison buprenorphine } \\
\text { was correlated with more } \\
\text { days of treatment after } \\
\text { release. }\end{array}$ & $\begin{array}{l}\text { Fewer women and mostly } \\
\text { African American } \\
\text { population; results may not } \\
\text { be generalizable. }\end{array}$ \\
\hline 5 & $\begin{array}{l}\text { Riggins } \\
\text { et al., } 2017\end{array}$ & Cohort & $\begin{array}{l}N= \\
305\end{array}$ & CJ & $\begin{array}{l}\text { Buprenorphine } \\
\text { treatment retention } \\
\text { among HIV-positive pa- } \\
\text { tients with a history of } \\
\text { incarceration. }\end{array}$ & $\begin{array}{l}\text { No significant differences in } \\
\text { groups }\end{array}$ & $\begin{array}{l}\text { Recently incarcerated were } \\
\text { more likely to be homeless, } \\
\text { unemployed, and } \\
\text { previously diagnosed with } \\
\text { mental illness. }\end{array}$ & $\begin{array}{l}\text { As an observational study, } \\
\text { clear causative relationships } \\
\text { could not be established. }\end{array}$ \\
\hline 6 & $\begin{array}{l}\text { Finlay } \\
\text { et al., } 2016\end{array}$ & RA & $\begin{array}{l}N=48 \\
689\end{array}$ & CJ & $\begin{array}{l}\text { Likelihood of US } \\
\text { Veterans to receive } \\
\text { treatment for opioid use } \\
\text { disorder at Veteran }\end{array}$ & $\begin{array}{l}\text { Veterans exiting prison } \\
\text { receive lowest rates of } \\
\text { treatment among all } \\
\text { justice-involved US }\end{array}$ & $\begin{array}{l}\text { Targeted efforts to reach } \\
\text { prison-involved veterans } \\
\text { necessary as they have low- } \\
\text { est odds of receipt. }\end{array}$ & $\begin{array}{l}\text { Study limited to veterans } \\
\text { who received treatment at } \\
\text { VHA facilities. }\end{array}$ \\
\hline
\end{tabular}

$\begin{array}{llllll}7 \begin{array}{l}\text { Sigmon } \\ \text { et al., 2015 }\end{array} & \begin{array}{l}\text { Pilot } \\ \text { study }\end{array} & N=10 & 0 & \begin{array}{l}\text { Feasibility of interim } \\ \text { buprenorphine } \\ \text { treatment to bridge } \\ \text { delays during patient } \\ \text { navigation. }\end{array} \\ 8 \begin{array}{l}\text { D'Onofrio } \\ 2015\end{array} & \text { RCT } & \begin{array}{l}N= \\ 329\end{array} & \text { ED } \begin{array}{l}\text { Determine success of } \\ \text { three intervention } \\ \text { options for ED patients } \\ \text { with OUD. }\end{array}\end{array}$

Health Association Veterans.

hospitals.

Opioid abstinence:70\% of participants retained through 12-week treatment program.

nterim treatment might reduce illicit drug use and drug-related risk behaviors among waitlisted.

After 30 days, group receiving buprenorphine reported greatest reduction of illicit opioid use per week.

9 Liebschutz RCT $N=$ et al., 2014

Methods of treatment among hospitalized patients post-discharge.

$\begin{array}{lll}10 \text { Gordon } & \text { RCT } & N= \\ \text { et al., } 2014 & & 211\end{array}$

\section{Success of buprenorphine treatment to addicted prison inmates nearing release versus after release}

11 Zaller Pilot $N=44 \quad C$ et al., 2013 study

Initiating treatment prior to release from incarceration and linking participants to community treatment.

$\begin{array}{lllll}12 \text { Schwarz } & \text { RA } & N= & \text { O } & \begin{array}{l}\text { Effect of treatment } \\ \text { retention on reducing } \\ \text { et al., 2012 }\end{array} \\ & 209 & & \text { ED utilization among }\end{array}$

Linkage (intervention) more likely to enter treatment in office setting than those in detox group (72\% vs. $11.9 \%)$.

In-prison treatment group more likely to continue treatment post-release; women more likely to complete prison treatment than men ( $86 \%$ vs $53 \%)$

Eleven of 32 participants remained in treatment for entire 6 months.

.

inct

buprenorphine treatment during incarceration; continuing in community is feasible; may increase retention postrelease.

Treatment retention was strongly correlated with a decline in ED visits (1
Buprenorphine

maintenance treatment significantly reduces ED
Unrandomized pilot trial with limited sample size.

Study involved only physicians approved to prescribe buprenorphine, May not be reflective most ED physicians.

Study conducted as single institution with an associated buprenorphine outpatient treatment program.

Study not generalizable to all geographic locations; $70 \%$ of participants were male.

Small sample size; selfreport nature of data, particularly drug use and criminal history.

Lack of randomization does not allow for control of selection. 
Table 2 Summary of included study characteristics and findings (Continued)

\begin{tabular}{|c|c|c|c|c|c|c|c|c|}
\hline \# & Article & $\begin{array}{l}\text { Study } \\
\text { Design }\end{array}$ & Sample & $\begin{array}{l}\text { Route } \\
\text { of } \\
\text { Entry }\end{array}$ & Intervention & Results & Conclusion & Limitations \\
\hline & & & & & $\begin{array}{l}\text { treatment seeking } \\
\text { patients. }\end{array}$ & $\begin{array}{l}\text { month }=1.6 \% \text { decline per } \\
\text { person). }\end{array}$ & utilization. & \\
\hline 13 & $\begin{array}{l}\text { Lee et al., } \\
2012\end{array}$ & Cohort & $\begin{array}{l}N= \\
142\end{array}$ & CJ & $\begin{array}{l}\text { Comparing treatment } \\
\text { retention and opioid } \\
\text { misuse among those } \\
\text { seeking treatment after } \\
\text { release from jail. }\end{array}$ & $\begin{array}{l}\text { Treatment retention over } \\
\text { time was similar between } \\
\text { groups. }\end{array}$ & $\begin{array}{l}\text { Primary care appears to a } \\
\text { feasible model of opioid } \\
\text { treatment once released } \\
\text { from incarceration. }\end{array}$ & $\begin{array}{l}\text { Study participants were } \\
\text { largely uninsured but } \\
\text { received treatment through } \\
\text { the study; whereas } \\
\text { uninsured community } \\
\text { referrals had no assistance. }\end{array}$ \\
\hline 14 & $\begin{array}{l}\text { Cropsey } \\
\text { et al., } 2011\end{array}$ & RCT & $N=36$ & CJ & $\begin{array}{l}\text { Efficacy of } \\
\text { buprenorphine for } \\
\text { relapse prevention } \\
\text { among women in } \\
\text { criminal justice system } \\
\text { transitioning to } \\
\text { community. }\end{array}$ & $\begin{array}{l}\text { Treatment was effective in } \\
\text { maintaining abstinence } \\
\text { compared to placebo ( } 92 \% \\
\text { placebo vs } 33 \% \\
\text { buprenorphine were opioid } \\
\text { positive per urinalysis). }\end{array}$ & $\begin{array}{l}\text { Initiating buprenorphine in } \\
\text { prison prior to release } \\
\text { appears to reduce opioid } \\
\text { use when participants } \\
\text { reenter community. }\end{array}$ & $\begin{array}{l}\text { Small sample size; limited } \\
\text { generality as participants } \\
\text { were women with criminal } \\
\text { justice involvement. }\end{array}$ \\
\hline 15 & $\begin{array}{l}\text { Wang } \\
\text { et al., } 2010\end{array}$ & RA & $\begin{array}{l}N= \\
166\end{array}$ & CJ & $\begin{array}{l}\text { Determine whether } \\
\text { history of incarceration } \\
\text { affects response to } \\
\text { primary care office- } \\
\text { based treatment. }\end{array}$ & $\begin{array}{l}\text { Participants with history of } \\
\text { incarceration have similar } \\
\text { treatment outcomes with } \\
\text { primary care office-based } \\
\text { treatment than those w/O } \\
\text { history of incarceration }\end{array}$ & $\begin{array}{l}\text { Formerly incarcerated } \\
\text { patients ar emore likely to } \\
\text { have been treated with } \\
\text { methadone, but do not } \\
\text { have substantially different } \\
\text { outcomes than those } \\
\text { without prior incarceration. }\end{array}$ & $\begin{array}{l}\text { Measurement of } \\
\text { incarceration was self- } \\
\text { reported and time incarcer- } \\
\text { ated was grouped (patients } \\
\text { with one month and multi- } \\
\text { years were in same group). }\end{array}$ \\
\hline 16 & $\begin{array}{l}\text { Marzo } \\
\text { et al., } 2009\end{array}$ & Cohort & $\begin{array}{l}N= \\
507\end{array}$ & CJ & $\begin{array}{l}\text { Describe the profile of } \\
\text { imprisoned French } \\
\text { opioid-dependent } \\
\text { patients }\end{array}$ & $\begin{array}{l}77 \% \text { of pts. received MAT at } \\
\text { imprisonment, these } \\
\text { patients were in poorer } \\
\text { health \& were more } \\
\text { isolated than other } \\
\text { population; } 238 / 478 \text { pts. } \\
\text { were re-incarcerated within } \\
3 \text { years }\end{array}$ & $\begin{array}{l}\text { MAT has increased in the } \\
\text { criminal justice system in } \\
\text { France, but maintenance } \\
\text { therapy not associated with } \\
\text { lower rate of } \\
\text { reincarceration. }\end{array}$ & $\begin{array}{l}\text { Conclusions on mortality } \\
\text { are not well-supported as } \\
\text { study was not designed for } \\
\text { mortality analysis; pt. selec- } \\
\text { tion not random }\end{array}$ \\
\hline 17 & $\begin{array}{l}\text { Magura } \\
\text { et al., } 2009\end{array}$ & $\mathrm{RCT}$ & $\begin{array}{l}N= \\
116\end{array}$ & CJ & $\begin{array}{l}\text { Test the efficacy of } \\
\text { buprenorohine versus } \\
\text { methadone while } \\
\text { incarcerated and follow- } \\
\text { up. }\end{array}$ & $\begin{array}{l}\text { Patients in buprenorphone } \\
\text { group reported to } \\
\text { treatment significantly } \\
\text { more than patients taking } \\
\text { methadone. }\end{array}$ & $\begin{array}{l}\text { There were no significant } \\
\text { differences between groups } \\
\text { for re-incarceration, relapse, } \\
\text { re-arrests. }\end{array}$ & $\begin{array}{l}\text { Findings may not be } \\
\text { generalizable in other } \\
\text { nations where methadone } \\
\text { distribution protocols vary. }\end{array}$ \\
\hline 18 & $\begin{array}{l}\text { D'Onofrio } \\
\text { et al., } 2017\end{array}$ & RA & $\begin{array}{l}N= \\
290\end{array}$ & ED & $\begin{array}{l}\text { Outcomes assessment of } \\
\text { previous RCTs to } \\
\text { determine long-term } \\
\text { outcomes. }\end{array}$ & $\begin{array}{l}\text { Patiengts in the } \\
\text { buprenorphine group } \\
\text { showed greater } \\
\text { engagement in treatement } \\
\text { at } 2 \text { months which was } \\
\text { statistically significant. }\end{array}$ & $\begin{array}{l}\text { Gains did not persist after } 2 \\
\text { months when measure at } \\
\text { the } 6 \text { and } 12 \text { month time } \\
\text { points. }\end{array}$ & $\begin{array}{l}\text { Buprenorphine treatment } \\
\text { initiatied in the ED was } \\
\text { associated with increased } \\
\text { engagement during } 2 \\
\text { month interval when } \\
\text { treatment was continued at } \\
\text { PCP. }\end{array}$ \\
\hline 19 & $\begin{array}{l}\text { Vocci et al., } \\
2015\end{array}$ & RA & $\begin{array}{l}N= \\
104\end{array}$ & CJ & $\begin{array}{l}\text { Assessed prior RCT to } \\
\text { examine if induction } \\
\text { into buprenorphine } \\
\text { during incareceration } \\
\text { was associated with } \\
\text { seeking treatment post- } \\
\text { release. }\end{array}$ & $\begin{array}{l}\text { Participants were rapidly } \\
\text { inducted onto } \\
\text { buprenorphine with no } \\
\text { serious side effects whle } \\
\text { incarecerated. }\end{array}$ & $\begin{array}{l}\text { Buprenorphine } \\
\text { administered to non-opioid } \\
\text { tolerant adults may be used } \\
\text { to reduce rates of with- } \\
\text { drawal and re-use post- } \\
\text { incarceration. }\end{array}$ & None noted. \\
\hline 20 & $\begin{array}{l}\text { Cushman } \\
\text { et al., } 2016\end{array}$ & RA & $\begin{array}{l}N= \\
113\end{array}$ & O & $\begin{array}{l}\text { To assess whether } \\
\text { inpatient initiation to } \\
\text { buprenorphine and } \\
\text { linkage to counselling } \\
\text { reduces illicit opioid use. }\end{array}$ & $\begin{array}{l}\text { Patients who were linked to } \\
\text { outpatients ervices versus } \\
\text { patients in detox (inpatient) } \\
\text { were more successful in the } \\
\text { short term. }\end{array}$ & $\begin{array}{l}\text { Differences did not persist } \\
\text { between groups (linking } \\
\text { versus detox) as far as } \\
\text { injection opiate use at 1, 3, } \\
\text { or } 6 \text { month timepoints. }\end{array}$ & $\begin{array}{l}\text { May not be generalizable } \\
\text { with a small population. }\end{array}$ \\
\hline
\end{tabular}

Abbreviations: RA Retrospective Analysis, $R C T$ Randomized Controlled Trial, $C J$ Criminal justice system, ED Emergency department, $O$ Outreach

\section{Criminal justice-associated entry into buprenorphine treatment}

Criminal justice-associated entry into buprenorphine treatment represents a majority of the articles. The studies presented here can be roughly conceptualized as three types with a main focus on: 1) offering buprenorphine treatment either pre- or post-release from incarceration; 2) incarceration status on buprenorphine treatment 
outcomes; and 3) effect of buprenorphine treatment on incarceration status or criminality.

\section{Pre- vs post-release buprenorphine}

A randomized controlled trial [32] and two secondary analyses [32,33] used a $2 \times 2 \times 2$ factorial design to explore the effects of in-prison treatment: buprenorphine or counselling only, post-release service center (opioid treatment center or community health center), and gender. Individuals assigned to the buprenorphine treatment condition were more likely to enter treatment than those assigned to counselling only and were more likely to enter community treatment after release. A follow-up study at 12 months [33] measured the following outcomes: days of community treatment, days of heroin use, crime, positive urinalysis for opioids or cocaine, and gender effects. Patients who initiated buprenorphine in prison had a higher number of days of community treatment but did not differ from the counselling only group on any other measures.

An earlier pilot study [34] reported on the feasibility of initiating buprenorphine prior to release on a small group $(n=44)$ of prisoners. Initiation of buprenorphine prerelease resulted in faster engagement with a prescriber post-release, as well as much longer treatment duration (24 vs 9 weeks). A pilot RCT examining women on parole or probation and found that at 12 weeks, when treatment concluded, buprenorphine was much more effective than placebo in reducing positive opioid urine tests. However, at a 3-month follow-up, there was no longer any difference [35].

\section{Incarceration status and buprenorphine effectiveness}

The next group of articles examines how incarceration status and prior incarceration history can impact the efficacy of buprenorphine treatment. In an analysis of a randomized control trial, the authors found that prior incarceration had no effect on either treatment retention or illicit drug use as measured by urinalysis [36]. The authors concluded that despite major demographic differences between previously versus never incarcerated, the effectiveness of buprenorphine was the same in both groups; and prescribing physicians can treat this patient population without bias. Two additional studies found similar results. In one cohort study, they found no differences in treatment retention between previously incarcerated versus community-referred groups [37]. In another multisite cohort study, they found that recent incarceration was not associated with any differences in 6- or 12month treatment retention or self-reported opioid use [38]. A large multi-site retrospective cohort study $(n=48$, 689) examined national Veterans Health Administration (VHA) clinical and pharmacy records of veterans diagnosed with opioid use disorder and found that veterans with criminal justice involvement had reduced odds of receiving MOUD compared to others [39].

\section{Buprenorphine treatment and incarceration status}

This group of articles examines how buprenorphine treatment impacts incarceration status and criminality. In this secondary analysis of a randomized clinical trial discussed earlier [35], the authors examined the effects of pre- and post-release buprenorphine initiation on arrest outcomes over a twelve-month period: rearrested, time to re-arrest, number of rearrests, and severity of charges [40]. The results found $43.1 \%$ were rearrested, but there was no effect of treatment condition on any arrest outcome measure. Similarly, a study that also included a methadone treatment group along with buprenorphine found that neither medication had any significant effects on re-arrest, severity of crime, or re-incarceration [41]. A larger prospective observational study of French prisoners $(n=507)$ looked at three-year outcomes and found that buprenorphine treatment was not associated with any change in the rate of reincarceration [42]. Another study concluded that the risk of re-incarceration and mortality remains high and further prevention is needed to elevate the health of this population [43]. In addition, the focus on re-incarceration rates, rather than treatment retention in general, could be problematic with these studies.

\section{Discussion}

We found modest evidence of programs that utilized nontraditional entry routes into buprenorphine treatment. Twenty studies published over this long time-frame is relatively low. The studies we did find were largely small pilot studies based in the northeast. Future research should focus on larger sample sizes, randomization, and broader geographic representation. Of the studies identified however, findings suggest that there is evidence that non-traditional routes can be used to engage patients with opioid use disorder into buprenorphine treatment. Greater access to non-traditional routes could improve awareness to treatment alternatives, which in turn could increase the number of patients who choose to engage in MOUD overall.

The hospital emergency department appears to present a significant opportunity to initiate treatment. Encouraging greater use of buprenorphine as standard of care in the ED could benefit a large number of patients. The studies identified suggest that buprenorphine in the ED could also be a cost-effective strategy, given its potential for greater availability and distribution [44, 45]. Yet most of these studies were conducted only out of a single city (New Haven), thus limiting generalizability across all regions and settings.

Outreach is another approach that can provide awareness and motivation for people who use drugs about available treatment options, as well as navigating them to treatment. We found only two articles that utilized community-based outreach: one using flyers distributed and posted throughout the community [29], and the other utilizing a mobile healthcare van linked to needle 
exchange [30]. An additional study [26] and its secondary analyses $[27,28]$, is considered outreach because patients, while hospitalized for other health problems, were actively engaged in buprenorphine treatment. Hospital-based outreach represents an ideal environment because not only can they be an effective site of screening, they can also initiate treatment without delay.

With regards to criminal justice, we found prisoners have a much higher rate of OUD and represent a great opportunity to increase access to treatment [46-48]. The studies we found looked at differences between pre- and post-release initiation of buprenorphine treatment. The premise is that initiating buprenorphine treatment prior to release may inoculate or protect patients upon release where they face a much higher risk of death during their first 2 weeks' postrelease. Providing prisoners greater opportunity to initiate MOUD treatment prior to release is a potential strategy.

There are policy considerations that could help increase access to buprenorphine treatment through nontraditional routes. Linkage to long-term maintenance treatment was mentioned by multiple studies, and identifying mechanisms to improve continuity of care beyond the initial induction of buprenorphine is worthy of additional research. Increasing access to buprenorphine through non-traditional routes is promising, but this still requires availability of treatment providers. While buprenorphine treatment has some distribution advantages over other medications, treatment gaps and barriers still exist. Removing these barriers, such as requiring a separate license waiver to treat and even the use of telemedicine for initial consultation, represents one opportunity to further increase access [49]. In addition, many of these specially licensed physicians are not actually treating OUD patients with buprenorphine, either because of stigma regarding OUD patients and treatment [50], financial factors [51], or other perceived negative factors $[50,52]$. Those with waivers tend to be in metropolitan areas, leaving a larger gap in rural counties [53].

From a public health perspective, additional resources should focus on outreach mechanisms that can identify patients and more proactively engage them into treatment earlier, rather than waiting for them to present at emergency departments or treatment facilities. Involvement from first responders, such as police and emergency medical services, to targeted neighborhoods impacted the most by the opioid epidemic could help improve awareness of treatment across communities. Encouraging and incentivizing a larger proportion of hospital emergency departments to initiate buprenorphine treatment will require significant changes in pharmacy formularies, reimbursement, and provider training. Yet, this investment in the ED as an early access point represents a significant opportunity for increasing access.
This research is novel in that while most studies have focused solely on analyzing access to potential treatment, limited evidence exists on mechanisms to increase rates of entry into treatment. We conclude that alternative routes to buprenorphine could reduce treatment delays for persons with opioid use disorder.

There are limitations to this research. First, as with all reviews, there is a possibility we did not include all articles because of our search terms, the databases we chose to query, or our relatively tight inclusion criteria. We also chose not to include articles or reports that were not published in peer-reviewed academic journals, which could limit the findings. While many of the studies we included were randomized designs, sample size, statistics, and outcomes were all varied. Despite these limitations, the strategies that we have reviewed in this research appear to be effective at improving treatment entry through nontraditional routes. Further research should examine other paths to entry and attempt to compare long-term outcomes of these non-traditional routes against more traditional paths. The implications from a policy perspective from these findings should also be explored.

\section{Conclusion}

Despite research suggesting that increasing the number of DEA-waivered physicians who prescribe buprenorphine would help with the opioid treatment gap, little research has been conducted on alternative routes to increase utilization of treatment. In this study, we found that identifying individuals through non-traditional routes-including criminal justice, emergency departments, and community outreach - can be used to engage a greater number of individuals to initiate MOUD treatment.

\section{Abbreviations \\ CJ: Criminal Justice; DATA 2000: Drug Addiction and Treatment Act of 2000; DEA: Drug Enforcement Agency; ED: Emergency Department; OUD: Opioid Use Disorder; RCT: Randomized Controlled Trial; SAMHSA: Substance Abuse and Mental Health Services Administration; US: United States; VHA: Veterans Health Administration}

\section{Acknowledgements}

Not Applicable.

\section{Authors' contributions}

TCL provides project oversight, conception, and writing on all versions. MWS performed the literature review, data analyses and was responsible for writing the initial draft of the manuscript. JRL provides subject matter expertise and final manuscript preparation. All authors read and approved the final manuscript.

\section{Funding}

The authors received no funding for this research.

\section{Availability of data and materials}

All data generated or analysed during this study are included in this published article and its supplementary information files.

Ethics approval and consent to participate Not Applicable. 


\section{Consent for publication}

Not Applicable.

\section{Competing interests}

The authors report no competing interests or conflicts. The authors alone are responsible for the content and writing of this article.

Received: 23 September 2019 Accepted: 9 January 2020 Published online: 20 January 2020

\section{References}

1. Kiang MV, Basu S, Chen J, Alexander MJ. Assessment of changes in the geographical distribution of opioid-related mortality across the United States by opioid type, 1999-2016. JAMA Netw Open. 2019;2(2):e190040. https:/doi. org/10.1001/jamanetworkopen.2019.0040 PubMed PMID: 30794299.

2. Substance Abuse and Mental Health Services Administration. Office of the Surgeon General (US). In: Facing Addiction in America: The Surgeon General's Spotlight on Opioids [Internet]. Washington (DC): US Department of Health and Human Services; 2018; 2018. Available from http://www.ncbi. nlm.nih.gov/books/NBK538436/ PubMed PMID: 30860690

3. Dick AW, Pacula RL, Gordon AJ, Sorbero M, Burns RM, Leslie D, Stein BD. Growth In Buprenorphine Waivers For Physicians Increased Potential Access To Opioid Agonist Treatment, 2002-11. Health Aff. 2015;34(6):1028-34.

4. Substance Abuse and Mental Health Services Administration. (2018). 2018 National Survey on Drug Use and Health: Methodological summary and definitions. Rockville: Center for Behavioral Health Statistics and Quality, Substance Abuse and Mental Health Services Administration. Retrieved from https://www.samhsa.gov/data/.

5. Sordo L, Barrio G, Bravo MJ, Indave Bl, Degenhardt L, Wiessing L, et al. Mortality risk during and after opioid substitution treatment: systematic review and meta-analysis of cohort studies. BMJ. 2017;357:j1550.

6. Huskamp HA, Busch AB, Souza J, Uscher-Pines L, Rose S, Wilcock A, Landon $B E$, Mehrotra A. How is telemedicine being used in opioid and other substance use disorder treatment? Health Aff. 2018:37(12):1940-7.

7. Alderks CE. Trends in the Use of Methadone, Buprenorphine, and Extendedrelease Naltrexone at Substance Abuse Treatment Facilities: 2003-2015 (Update). The CBHSQ Report: August 22, 2017. Center for Behavioral Health Statistics and Quality, Substance Abuse and Mental Health Services Administration, Rockville.

8. Substance Abuse and Mental Health Services Administration. DATA 2000 Practitioner and Program Data. Report accessed at https://www.samhsa. gov/medication-assisted-treatment/training-materials-resources/practitionerprogram-data on September 1 2019. Center for Behavioral Health Statistics and Quality, Substance Abuse and Mental Health Services Administration, Rockville, MD.

9. Rosenblatt RA, Andrilla CH, Catlin M, Larson EH. Geographic and specialty distribution of US physicians trained to treat opioid use disorder. Ann Fam Med. 2015;13(1):23-6. https://doi.org/10.1370/afm.1735 PubMed PMID: 25583888.

10. Bhatraju EP, Grossman E, Tofighi B, McNeely J, DiRocco D, Flannery M, Garment A, Goldfeld K, Gourevitch MN, Lee JD. Public sector low threshold office-based buprenorphine treatment: outcomes at year 7. Addict Sci Clin Pract. 2017;12(1):7. https://doi.org/10.1186/s13722-017-0072-2 PubMed PMID: 28245872

11. Martin SA, Chiodo LM, Bosse JD, Wilson A. The next stage of buprenorphine Care for Opioid use Disorder. Ann Intern Med. 2018;169(9):628-35. https:// doi.org/10.7326/M18-1652 Epub 2018 Oct 23. PubMed PMID: 30357262.

12. Marteau D, McDonald R, Patel K. The relative risk of fatal poisoning by methadone or buprenorphine within the wider population of England and Wales. BMJ Open. 2015;5(5):e007629. https://doi.org/10.1136/bmjopen-2015007629 PubMed PMID: 26024998.

13. Langabeer J, Gourishankar A, Chamber K, Giri S, Madu R, ChampagneLangabeer T. Disparities between U.S. Opioid Overdose Deaths and Treatment Capacity: A Geospatial and Descriptive Analysis. J Addict Med. 2018. https://doi.org/10.1097/ADM.0000000000000523.

14. Hawk K, D'Onofrio G. Emergency department screening and interventions for substance use disorders. Addict Sci Clin Pract. 2018;13(1):18. https://doi. org/10.1186/s13722-018-0117-1 Review. PubMed PMID: 30078375.

15. D'Onofrio G, McCormack RP, Hawk K. Emergency departments - A 24/7/365 option for combating the opioid crisis. N Engl J Med. 2018;379(26):2487-90. https://doi.org/10.1056/NEJMp1811988 PubMed PMID: 30586522.
16. Pollini RA, McCall L, Mehta SH, Vlahov D, Strathdee SA. Non-fatal overdose and subsequent drug treatment among injection drug users. Drug Alcohol Depend. 2006;83(2):104-10 Epub 2005 Nov 23. PubMed PMID: 16310322.

17. Vivolo-Kantor AM, Seth P, Gladden RM, Mattson CL, Baldwin GT, Kite-Powell A, Coletta MA. Vital Signs: Trends in Emergency Department Visits for Suspected Opioid Overdoses - United States, July 2016-September 2017. MMWR Morb Mortal Wkly Rep. 2018;67(9):279-85. https://doi.org/10.15585/ mmwr.mm6709e1 PubMed PMID: 29518069.

18. 19a, Banta-Green CJ, Floyd AS, Vick K, Arthur J, Hoeft TJ, Tsui JI. Opioid Use Disorder Treatment Decision Making And Care Navigation Upon Release From Prison: A Feasibility Study. Subst Abus Rehabil. 2019;10:57-67. Published 2019 Oct 22. https://doi.org/10.2147/SAR.S192045.

19. Krawczyk N, Picher CE, Feder KA, Saloner B. Only one in twenty justicereferred adults in specialty treatment for opioid use receive methadone or buprenorphine. Health Aff (Millwood). 2017;36(12):2046-53. https://doi.org/ 10.1377/hlthaff.2017.0890 PubMed PMID: 29200340.

20. Kwiatkowski CF, Booth RE, Lloyd LV. The effects of offering free treatment to street-recruited opioid injectors. Addiction. 2000;95(5):697-704 PubMed PMID: 10885044

21. Mattick RP, Kimber J, Breen C, Davoli M. Buprenorphine maintenance versus placebo or methadone maintenance for opioid dependence. Cochrane Database Syst Rev. 2004;(3):CD002207. Review. Update in: Cochrane Database Syst Rev. 2008;(2):CD002207. PubMed PMID: 15266465

22. US Congress. S.524-Comprehensive Addiction and Recovery Act of 2016 Pub L No. 114-198. https://www.congress.gov/bill/114th-congress/senatebill/524/text. Accessed November 21, 2019.

23. Ouzzani M, Hammady H, Fedorowicz Z, Elmagarmid A. Rayyan - a web and mobile app for systematic reviews. Syst Rev. 2016;5:210. https://doi.org/ 10.1186/s13643-016-0384-4.

24. D'Onofrio G, O'Connor PG, Pantalon MV, Chawarski MC, Busch SH, Owens PH, Bernstein SL, Fiellin DA. Emergency department-initiated buprenorphine/ naloxone treatment for opioid dependence: a randomized clinical trial. JAMA. 2015;313(16):1636-44. https://doi.org/10.1001/jama.2015.3474.

25. D'Onofrio G, Chawarski MC, O'Connor PG, Pantalon MV, Busch SH, Owens PH, Hawk K, Bernstein SL, Fiellin DA. Emergency department-initiated buprenorphine for opioid dependence with continuation in primary care: outcomes during and after intervention. J Gen Intern Med. 2017;32(6):660-6. https://doi.org/10.1007/s11606-017-3993-2 Epub 2017 Feb 13.

26. Busch SH, Fiellin DA, Chawarski MC, Owens PH, Pantalon MV, Hawk K, Bernstein SL, O'Connor PG, D'Onofrio G. Cost-effectiveness of emergency department-initiated treatment for opioid dependence. Addiction. 2017; 112(11):2002-10. https://doi.org/10.1111/add.13900 Epub 2017 Aug 16.

27. Liebschutz JM, Crooks D, Herman D, Anderson B, Tsui J, Meshesha LZ, Dossabhoy S, Stein M. Buprenorphine treatment for hospitalized, opioiddependent patients: a randomized clinical trial. JAMA Intern Med. 2014 Aug 174(8):1369-76. https://doi.org/10.1001/jamainternmed.2014.2556.

28. Cushman PA, Liebschutz JM, Anderson BJ, Moreau MR, Stein MD. Buprenorphine initiation and linkage to outpatient buprenorphine do not reduce frequency of injection opiate use following hospitalization. J Subst Abus Treat. 2016;68:68-73. https://doi.org/10.1016/j.jsat.2016.06.003 Epub 2016 Jun 11

29. Lee CS, Liebschutz JM, Anderson BJ, Stein MD. Hospitalized opioiddependent patients: exploring predictors of buprenorphine treatment entry and retention after discharge. Am J Addict. 2017;26(7):667-72. https://doi. org/10.1111/ajad.12533 Epub 2017 Mar 21.

30. Sigmon SC, Meyer A C, Hruska B, Ochalek T, Rose G, Badger GJ, Brooklyn JR, Heil SH, Higgins ST, Moore BA, Schwartz RP. Bridging waitlist delays with interim buprenorphine treatment: initial feasibility. Addict Behav. 2015;51: 136-42. https://doi.org/10.1016/j.addbeh.2015.07.030 Epub 2015 Jul 29.

31. Schwarz R, Zelenev A, Bruce RD, Altice FL. Retention on buprenorphine treatment reduces emergency department utilization, but not hospitalization, among treatment-seeking patients with opioid dependence. J Subst Abus Treat. 2012:43(4):451-7. https://doi.org/10.1016/j.jsat.2012.03.008 Epub 2012 Apr 24

32. Gordon MS, Kinlock TW, Schwartz RP, Fitzgerald TT, O'Grady KE, Vocci FJ. A randomized controlled trial of prison-initiated buprenorphine: prison outcomes and community treatment entry. Drug Alcohol Depend. 2014;142:33-40. https://doi.org/10.1016/j.drugalcdep.2014.05.011 Epub 2014 Jun 2.

33. Vocci FJ, Schwartz RP, Wilson ME, Gordon MS, Kinlock TW, Fitzgerald TT, O'Grady KE, Jaffe $\mathrm{JH}$. Buprenorphine dose induction in non-opioid-tolerant pre-release prisoners. Drug Alcohol Depend. 2015;156:133-8. https://doi.org/ 10.1016/j.drugalcdep.2015.09.001 Epub 2015 Sep 7. 
34. Gordon MS, Kinlock TW, Schwartz RP, O'Grady KE, Fitzgerald TT, Vocci FJ. A randomized clinical trial of buprenorphine for prisoners: findings at 12months post-release. Drug Alcohol Depend. 2017;172:34-42. https://doi.org/ 10.1016/j.drugalcdep.2016.11.037 Epub 2017 Jan 11.

35. Zaller N, McKenzie M, Friedmann PD, Green TC, McGowan S, Rich JD. Initiation of buprenorphine during incarceration and retention in treatment upon release. J Subst Abus Treat. 2013;45(2):222-6. https://doi.org/10.1016/j. jsat.2013.02.005 Epub 2013 Mar 27.

36. Cropsey KL, Lane PS, Hale GJ, Jackson DO, Clark CB, Ingersoll KS, Islam MA, Stitzer ML. Results of a pilot randomized controlled trial of buprenorphine for opioid dependent women in the criminal justice system. Drug Alcohol Depend. 2011;119(3):172-8. https://doi.org/10.1016/j.drugalcdep.2011.06.021 Epub 2011 Jul 23.

37. Wang EA, Moore BA, Sullivan LE, Fiellin DA. Effect of incarceration history on outcomes of primary care office-based buprenorphine/naloxone. J Gen Intern Med. 2010;25(7):670-4. https://doi.org/10.1007/s11606-010-1306-0 Epub 2010 Mar 6.

38. Lee JD, Grossman E, Truncali A, Rotrosen J, Rosenblum A, Magura S, Gourevitch MN. Buprenorphine-naloxone maintenance following release from jail. Subst Abus. 2012;33(1):40-7. https://doi.org/10.1080/08897077. 2011.620475.

39. Riggins DP, Cunningham CO, Ning Y, Fox AD. Recent incarceration and buprenorphine maintenance treatment outcomes among human immunodeficiency virus-positive patients. Subst Abus. 2017;38(3):297-302. https://doi.org/10.1080/08897077.2016.1220443 Epub 2016 Aug 11.

40. Finlay AK, Harris AH, Rosenthal J, Blue-Howells J, Clark S, McGuire J, Timko C, Frayne SM, Smelson D, Oliva E, Binswanger I. Receipt of pharmacotherapy for opioid use disorder by justice-involved U.S. veterans health Administration patients. Drug Alcohol Depend. 2016;160:222-6. https://doi. org/10.1016/j.drugalcdep.2016.01.013 Epub 2016 Jan 24.

41. Gordon MS, Blue TR, Couvillion K, Schwartz RP, O'Grady KE, Fitzgerald TT, Vocci FJ. Initiating buprenorphine treatment prior to versus after release from prison: arrest outcomes. Drug Alcohol Depend. 2018;188:232-8. https://doi.org/10.1016/j.drugalcdep.2018.04.010 Epub 2018 May 12.

42. Marzo JN, Rotily M, Meroueh F, Varastet M, Hunault C, Obradovic I, Zin A. Maintenance therapy and 3-year outcome of opioid-dependent prisoners: a prospective study in France (2003-06). Addiction. 2009;104(7):1233-40. https://doi.org/10.1111/j.1360-0443.2009.02558xx Epub 2009 Apr 29.

43. Magura S, Lee JD, Hershberger J, Joseph H, Marsch L, Shropshire C, Rosenblum A. Buprenorphine and methadone maintenance in jail and postrelease: a randomized clinical trial. Drug Alcohol Depend. 2009;99(1-3):22230. https://doi.org/10.1016/j.drugalcdep.2008.08.006 Epub 2008 Oct 18.

44. National Academies of Sciences, Engineering, and Medicine; Health and Medicine Division; Board on Health Sciences Policy; Committee on Medication-Assisted Treatment for Opioid Use Disorder; Mancher M, Leshner Al, editors. Medications for Opioid Use Disorder Save Lives. Washington (DC): National Academies Press (US); 2019 Mar 30. PubMed PMID: 30896911.

45. Buprenorphine/Naloxone Versus Methadone for the Treatment of Opioid Dependence: A Review of Comparative Clinical Effectiveness, CostEffectiveness and Guidelines [Internet]. Ottawa (ON): Canadian Agency for Drugs and Technologies in Health; 2016 Sep 2. Available from http://www. ncbi.nlm.nih.gov/books/NBK385163/ PubMed PMID: 27656728.

46. Binswanger IA. Opioid use disorder and incarceration - Hope for ensuring the continuity of treatment. N Engl J Med. 2019;380(13):1193-5.

47. Rich JD, Boutwell AE, Shield DC, Key RG, McKenzie M, Clarke JG. Friedmann. PD. attitudes and practices regarding the use of methadone in US state and federal prisons. J Urban Health. 2005;82(3):411-9.

48. Berg J. Breaking the cycle: medication assisted treatment (MAT) in the criminal justice system. Substance Abuse and Mental Health Services Administration [internet]. Washington (DC): US Department of Health and Human Services; 2019. Available from https://blog.samhsa.gov/2019/03/15/ breaking-the-cycle-medication-assisted-treatment-mat-in-the-criminaljustice-system

49. Andrilla CHA, Coulthard C, Larson EH. Barriers rural physicians face prescribing buprenorphine for opioid use disorder. Ann Fam Med. 2017; 15(4):359-62. https://doi.org/10.1370/afm.2099 PubMed PMID: 28694273.

50. Huhn AS, Dunn KE. Why aren't physicians prescribing more buprenorphine? J Subst Abus Treat. 2017;78:1-7. https://doi.org/10.1016/j.jsat.2017.04.005 Epub 2017 Apr 12. PubMed PMID: 28554597.
51. Knudsen HK, Roman PM. Financial factors and the implementation of medications for treating opioid use disorders. J Addict Med. 2012;6(4):280-6. https://doi.org/10.1097/ADM.0b013e318262a97a PubMed PMID: 22810057.

52. Andrilla CHA, Coulthard C, Patterson DG. Prescribing Practices of Rural Physicians Waivered to Prescribe Buprenorphine. Am J Prev Med. 2018; 54(6S3):S208-14. https://doi.org/10.1016/j.amepre.2018.02.006 PubMed PMID: 29779544

53. Andrilla CHA, Moore TE, Patterson DG, Larson EH. Geographic distribution of providers with a DEA waiver to prescribe buprenorphine for the treatment of opioid use disorder: A 5-year update. J Rural Health. 2019;35(1):108-12. https://doi.org/10.1111/jrh.12307 Epub 2018 Jun 20. PubMed PMID: 2992363.

\section{Publisher's Note}

Springer Nature remains neutral with regard to jurisdictional claims in published maps and institutional affiliations.
Ready to submit your research? Choose BMC and benefit from:

- fast, convenient online submission

- thorough peer review by experienced researchers in your field

- rapid publication on acceptance

- support for research data, including large and complex data types

- gold Open Access which fosters wider collaboration and increased citations

- maximum visibility for your research: over $100 \mathrm{M}$ website views per year

At BMC, research is always in progress.

Learn more biomedcentral.com/submissions 